\title{
Rancang Bangun Teologi “Kekudusan” Tentang Hamba Tuhan Sebagai Pemimpin Kristen Menurut Kitab Yosua
}

\author{
Zulkisar Pardede \\ Sekolah Tinggi Alkitab Jember \\ zulkisar@gmail.co.id
}

\begin{abstract}
Leadership is the key in Christianity. This article aims to present Joshua's leadership pattern in leading the nation of Israel. The method used is the study of the exposition of the book of Joshua with a descriptive method to describe Joshua's leadership at that time. The conclusion of this discussion is that Joshua's leadership emphasizing holiness is an ideal pattern in the leadership of God's servants today.
\end{abstract}

Keywords: holiness; Joshua; leadership; servant of the Lord

\begin{abstract}
Abstrak
Kepemimpinan merupakan kunci dalam kekristenan. Artikel ini bertujuan untuk menampilkan pola kepemimpinan Yosua dalam memimpin bangsa Israel. Metode yang digunakan adalah kajian eksposisi kitab Yosua dengan metode deskriptif untuk menggambarkan kepemimpinan Yosua pada masa itu. Kesimpulan dari pembahsan ini adalah, kepemimpinan Yosua yang menekankan kekudusan merupakan pola ideal dalam kepemimpinan hamba Tuhan masa kini.
\end{abstract}

Kata Kunci: hamba Tuhan; kekudusan; kepemimpinan; Yosua

\section{PENDAHULUAN}

Kata "Kekudusan" berarti suci, murni, menganggap suci. ${ }^{1}$ Kudus segala sesuatu yang terpisahkan (dikhususkan) dari kebiasaan atau hal-hal yang duniawi adalah "kudus". Karena itu di atas semuanya. Allah adalah Kudus (Yesaya 6:3) " sebab ada tertulis, kuduslah kamu sebab Aku kudus (1 Petrus 1:16). Karena Allah Kudus (suci) maka kudus jugalah setiap orang yang hidup di dalam Tuhan bahkan mereka yang terlibat dalam pelayanan di gereja. Tetapi Alkitab menjelaskan bahwa semua manusia itu sudah berbuat dosa dan telah kehilangan kemuliaan Allah (Rom. 3:23). Mustahil manusia berdosa bisa menghampiri hadirat Tuhan untuk memohon berkat bagi jemaat jika hidupnya tidak berkenan di dahadapan Tuhan. Demikian juga seorang pemimpin dalam lingkup keluarga,

\footnotetext{
${ }^{1}$ KBBI, "Kudus" Balai Pustaka, 471

${ }^{2}$ W.R.F. Browning, Kamus Alkitab, (Jakarta: BPK Gunung Mulia, 2011),230
} 
gereja dan hamba Tuhan yang melayani dalam gereja. Memahami betapa pentingnya hidup kudus dihadapan Tuhan merupakan pemikiran yang telah mendapatkan pencerahan oleh Firman Tuhan, diperlukan komitmen untuk melakukan kehendakNya. Dalam Alkitab kekudusan atau kesucian berarti pemisahan dari segala hal yang biasa atau najis. ${ }^{3}$ Berkenaan dengan Allah, kekudusan berarti tidak hanya bahwa Ia terpisah dari segala sesuatu yang najis dan jahat, tetapi juga bahwa Ia nyata-nyata bersih dan karenanya berbeda dari semua orang lain. Jika kekudusan tidak dapat dipertahankan didalam gereja, ajaran Iman Kristen maka taruhannya, bahwa Isu aborsi yang terjadi dan semakin meningkat menurut penelitian adalah kurangnya ajaran iman mengenal kekudusan Allah dan manusia atau perlu dipertajam lagi, kedaulatan Allah dan kesucian hidup. Semua orang Kristen percaya bahwa Allah yang mengambil hidup. Di satu pihak Dialah yang memberikan hidup dan nafas dan segala sesuatu kepada semua orang (Kej17:25), di dalam Dia kita hidup, kita bergerak, kita ada ${ }^{4}$

Komentar Raimon Panikkar tentang masyarakat pluralistis modern adalah sebagai berikut: pluralism adalah problem eksistensi manusia zaman ini yang memunculkan pertanyaan-pertanyaan tajam tentang bagaimana kami hidup akan hidup di tengah-tengah egitu banyak pilihan. Taiap-tiap hari menghadapi dilemma yang nyata-nyata terjadi mealui kontak timbale balik yang tidak cocol dengan "world-view" dan filsafat hidup. ${ }^{5}$

Terdapat beberapa alasan mengapa lingkungan yang dihidupi sekarang ini memberi rangsangan untuk hidup bebas. Perilaku untuk melakukan hubungan seks secara bebas dapat dilakukan di mobil, hotel; sebuah kejahatan pornografi dan pornoaksi. Emansipasi, hak azasi dan modernisasi juga menjadi alasan yang merangsang manusia modern untuk hidup dalam pergaulan bebas. ${ }^{6}$ Pernikahan yang membosankan karena kegiatan rumah dikerjakan hanya sebagai rutinitas juga menjadi atakan psikologis membuat suami atau istri mencari yang lain. Suami atau istri yang ingin jadi popular atau ingin cepat kaya, haus kemewaan. Semua ini menjadi ransangan psikologis yang membuat pasutri masuk dalam pergaulan bebas.

Kekudusan adalah sifat yang Allah inginkan untuk diketahui secara khusus dalam Perjanjian Lama (Im. 11:44; Maz. 99:3,5,9; Yes. 40:25; Hab.1:12). Secara spesifik pada kitab Yosua yang membahas tentang kekudusan dalam penulisan ini. Kata Perjanjian Lama "kekudusan" pada hakikatnya menyampaikan pengertian "pemisahan" perkara-perkara sekular untuk pelayanan dan atau penyembahan pada Yahweh, yang juga terpisah sama

\footnotetext{
${ }^{3}$ Chales C. Ryrie, Teologi Dasar 1(Jakarta: Yayasan ANDI, 1991), 51

${ }^{4}$ John Stott, Isu-Isu Global, (Jakarta: Yayasan Bina Kasih, 1991),402

${ }^{5}$ Harry James Cargas, Invisible Harmony (Minneapolis: Fortress, 1997),56

${ }^{6}$ Marulak Pasaribu, Pernikahan dan Keluarga Kristen, (Batu: Lit. YPPII, 2004),8
} 
sekali dengan dari ciptaanNya. ${ }^{7}$ Sedangkan dalam Perjanjian Baru di dalam pernyataanpernyataan langsung (Yoh 17:11; 1 Pet. 1:15; Wah. 4:8; 1 Yoh 1:15). Konsep kekudusan dalam Perjanjian Baru melalui penebusan oleh Yesus Kristus berbeda dengan konsep Perjanjian Lama. Tetapi prinsipnya menurut Alkitab Kesucian Allah menjadi standar bagi kehidupan dan kelakuan orang percaya (1 Yoh.1:5).

\section{Yosua sebagai Sosok Pemimpin yang Taat dan Setia kepada Tuhan}

Cukup banyak yang menandai Yosua sebagai seorang pemimpin. Dia adalah keturunan keluarga Yusuf, yang mempunyai wibawa terbesar pada saat itu dalam sejarah Israel; Kakeknya memimpin suku Efraim di padang gurun (1 Taw. 7:27; Bil. 1:10); sebagai orang yang lahir dan dibesarkan di Mesir, dia telah dipersiapakan, sama seperti Musa, untuk tugas sebagai pemimpin bangsa; sebagai rekan pembantu Musa, sudah jelas bahwa dia sangat memenuhi syarat untuk menggenatikannya; sebagai rekan Musa di Gunung Sinai (Kel. 24:13) dan sebagai pengurus kemah Suci (Kel.33:11). Kepemimpinan Yosua telah dinyatakan dan diakui. Imam dan keberaniannya telah menjadi nyata melalui laporan yang diberikannnya bersama-sama dengan Kaleb sesudah mereka mengintai tanah Kanaan. Kecakapannya sebagai pemimpin meliter sudah diperlihatkannya dalam menghadapi serangan dari orang-orang Amalek. Lebih dari semuanya itu, Yosua telah dipanggil serta diteguhkan oleh Tuhan sendiri (Ul. 31:23), dan kuasa rohani Musa telah diteruskan kepadanya (Ul. 34:9) ${ }^{8}$

Yosua adalah salah seorang tokoh terkemuka dari Perjanjian Lama: Pembantu Musa(Kel. 24:13; 32:17; 33:11), seorang dari 12 pengintai (Bil.14), jendral yang sangat berhasil. Seorang pemberani dan saleh, ia melayani sebagai alat Tuhan untuk membawa orang Israel memasuki Negeri Perjanjian. Sudah sepentasnya kitab ini memakai namanya, tetapi akhirnya perlu di sadari kitab tersebut tidak berkisah mengenai Yosua melainkan mengenai Allah. ${ }^{9}$

Orang Israel beribadah dan patuh kepada Tuhan sepanjang zaman Yosua dan sepanjang tua-tua yang hidup lebih lama dari pada Yosua (Yos. 24:31; Hak.2:7). Sikap taat dan setia ini memang sesuai dengan sumpah-setia yang diangkat oleh segenap umat itu, sebelumnya mereka mulai bergerak maju (Yos.1:16-18). Ketaatan kepada Tuhan dalam hal ini tidak diukur menurut undang-undang Taurat seluruhnya, melainkan semata-mata dipusatkan kepada suatu kepatuhan yang bulat terhadap Yosua saja: mentaati perintahperintah Yosua, itulah yang berarti beribadah kepada Tuhan. ${ }^{10}$

\footnotetext{
${ }^{7}$ Andrew E. Hill \& John H. Walton, Survei Perjanjian Lama, (Malang:Gandum Mas, 2013), 132

${ }^{8}$ Denis Green, Pengenalan Perjanjian Lama, (Malang: Gandum Mas, 1995),75

${ }^{9}$ Survei Perjanjian Lama, 220.

${ }^{10}$ C. Barth, Theologia Perjanjian Lama 2, (Jakarta: BPK Gunung Mulia, 1981),17
} 
Unsur keterlibatan Allah yang Maha Kuasa tidak dapat dilepaskan dari kitab Yosua tanpa merusak sama sekali maksud teologis yang terdapat di dalamnya. Kitab ini menandakan bahwa Tuhan Yang Mahakuasa bertindak di dalam sejarah dengan maksud untuk melaksanakan rencana-Nya dan menggenapi janji-Nya.

\section{Inti Ajaran dari Kitab Yosua}

Pertama: Kesetiaan Tuhan-Jauh sebelumnya, Tuhan telah menyatakan rencana-Nya bahwa orang Israel akan memiliki Tanah yang dijanjikan-Nya. Rupa-rupanya tujuan Tuhan itu kemudian digagalkan oleh dosa dan ketidak taatan manusia; tetapi rencana Allah tidak dapat dibatalkan, dan kitab ini menceritakan realisasi janji Tuhan serta pelaksanaan rencana-Nya (Yosua 11:23; 21:43-45; 23:14).

Kedua: Kekudusan Tuhan-melalui hukumNya atas penduduk Kanaan yang asli. Israel menjadi alat penghukuman Allah (Yos. 6:17; 11:20; 23:3), tetapi kekudusanNya tidak kurang diperlihatkan pula melalui perintahNya bahwa alat itu juga harus kudus. Ditegaskan berulang kali bahwa ini adalah perperangan suci, dan bahwa Israel akan berhasil hanya kalau mereka membinasakan semua kejahatan $(3: 5 ; 7: 11-13 ; 23: 12-13$; $24: 19-20){ }^{11}$

Ketiga: Keselamatan dari Tuhan-Nama "Yosua" berarti"Yehowah adalah keselamatan", dan kitab Yosua menggambarkan aspek keselamatan yang cukup penting. Nama Yosua juga sama dengan "Yesus", maka banyanga Kristus dapat dilihat di sini. Seperti Yosua memimpin orang Israel masuk tanah Perjanjian, demikian Kristus memimpin kita kepada keselamatan( Ibrani 2:10). Seperti Yosua memimpin orang Israel kepada kemenangan atas musuh-musuh mereka, demikian Kristus memungkinkan kemenangan kita atas dosa dan Iblis (Ibrani 2:14-15; 1 Yoh. 3:8). Seperti Yosua berdoa untuk orang Israel waktu mereka berbuat dosa dan dikalahkan, demikianlah Yesus menjadi pengatara kepada Bapa bagi kita (ibr. 7:25; 1 Yoh.2:1). Seperti Yosua memberikan tempat perhentian kepada suku Israel waktu tanah Kanaan dibagi-bagikan, demikianlah Kristus memberikan tempat perhentian kepada semua orang percaya (Ibr. 4:1, 8-11).

\section{PEMBAHASAN}

\section{Kekudusan dan Pengabdian diri kepada Allah}

Kekudusan kata dasarnya "kudus artinya suci, murni. ${ }^{12}$ Memiliki sifat kudus, memiliki sifat kudus.Pengertian pengabdian diri kepada Allah. Kata Pengabdian menurut Kamus Besar Bahasa Indonesia dari kata dasarnya abdi adalah "hamba; orang bawahan (2)

\footnotetext{
${ }^{11}$ Denis Grenn,Pengenalan Perjanjian Lama, 80

${ }^{12} \mathrm{KBBI}$, hal 471.
} 
budak tebusan (3) pegawai. ${ }^{13}$ Kata kerja bentuk Pasif Mengabdi artinya "menghamba; menghambakan diri; berbakti. ${ }^{14}$

Lebih Khusus lagi mengabdikan diri, kata "abdi” (bahasa Ibrani eved) menunjuk kepada hamba. ${ }^{15}$ Menurut ensiklopedia Alkitab praktis artinya "budak; hamba. ${ }^{16}$ Hamba, budak mengabdikan diri, menghambakan diri dan berbakti kepada Tuhan diperintahkan suapaya Kudus yaitu memiliki sifat kudus, suci dengan melepaskan diri dari perbuatan kotor atau dosa. Dalam Alkitab berarti pemisahan dari segala hal yang biasa atau najis. Berkenaan dengan Allah, kesucian berarti tidak hanya bahwa Ia terpisah dari segala sesuatu yang najis dan jahat, tetapi juga bahwa Ia nyata-nyata bersih dan karenanya berbeda dari segala yang lain. Kesucian di dalam Allah, kesucaiannya adalah kemurnian keberadaan dan sifat serta kehendak dan tindakan. ${ }^{17}$ Hubungan dengan Yosua 3:5"... Tuhan akan melakukan perbuatan yang ajaib di antara mereka yang menghambakan diri kepada Tuhan

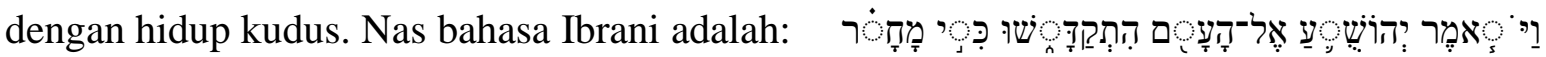

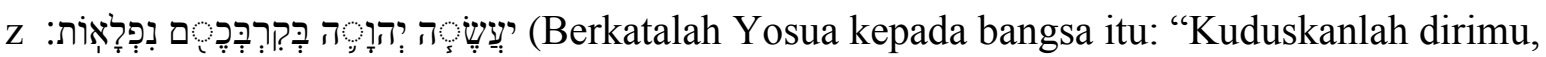
sebab besok TUHAN akan melakukan perbuatan yang ajaib di antara kamu).

Kata kuduskanlah diterjemahkan oleh KJV dan RSV "Sanctify" tetapi oleh NAS dan NIV diterjemahkan "consecrate." Kata sanctify adalah kata kerja Kekudusan dan menyucikan sedangkan kata consecrate" mentahbiskan dan mengabdikan kata sifatnya dari adalah kudus. Jadi KJV/ RSV dari bahasa Ibrani kata holy, be sanctified (menjadi kudus dan menjadi suci). Dari terjemahan NAS/NIV yang berbeda kata consecrate artinya mentahbiskan dan mengabdikan dari bahasa Ibrani (qadash) to be set apart or consecrated kata keterangan berpisahan dan terlepas. Kata Kuduskanlah adalah kata kerja dari kata kekudusan dan menyucikan yaitu dipisahkan dan terlepas kata $\grave{\gamma} \gamma v i ́ \sigma \alpha \sigma \theta \varepsilon$ (verb imperative aorist middle $2^{\text {nd }}$ person plural dari kata $\grave{\alpha} \gamma v i ́ \zeta \omega$. Cleanse from efilement artinya bersih dari yang kotor. Kata kerja bentuk lampau yang terjadi sekali waktu lampau dan tidak terulang kembali, orang kedua jamak yaitu yaitu kalian. Kekudusan adalah (orang-orang) yang mengabdikan diri memiliki sifat "kudus" kata kerjanya menyucikan diri, menjadi kudus/suci yaitu melepaskan diri dari perbuatanperbuatan kotor. Jadi Kekudusan menurut alkitab adalah orang-orang yang mengabdikan diri kepada Tuhan dengan memiliki sifat Kudus dan menjadikan dirinya suci dengan melepaskan diri dari perbuatan kotor seperti dosa.

\footnotetext{
${ }^{13}$ Ibid, 1

${ }^{14}$ Ibid.

${ }^{15}$ D.L. Baker. dkk, Pengantar Bahasa Ibrani, (Jakarta:BPK Gunung Mulia, 2010), 121

${ }^{16}$ W.N McElrath, Billy Mathias, Ensiklopedia Alkitab Praktis.(Bandung: Yayasan Baptis Indonesia,

${ }^{17}$ Chales R. Ryrie, Theologi Dasar I, (Yogyakarta: Yayasan Andi, 1991), 51

${ }^{18}$ Bible Work 8
} 2012),7 


\section{Hamba Tuhan Berhubungan dengan Moral (Morally) \\ Masalah Moral Seksualitas}

Menurut Kamus Besar Bahasa Indonesia kata moral (morally) adalah (1) ajaran tentang baik buruk yang diterima umum mengenai perbuatan, sikap, kewajiban, dsb; akhlak; budi pekerti; susila (2) Kondisi mental yang membuat orang tetap berani, bersemangat, bergairah, berdisiplin (3) ajaran kesusilahan yang ditarik dari suatu cerita. ${ }^{19}$ Morally menurut kamus Bahasa Inggris artinya "secara moral" ${ }^{20}$ Moralis adalah (1) orang yang selalu mementingkan moral (2) orang yang mengajarkan atau mempelajari moral sebagai cabang filsafat.(3) orang yang menaruh perhatian terhadap pengaturan moral orang lain. Alkitab (BGT) memakai kata "ŏ yıós adjective normal nominative masculine singular

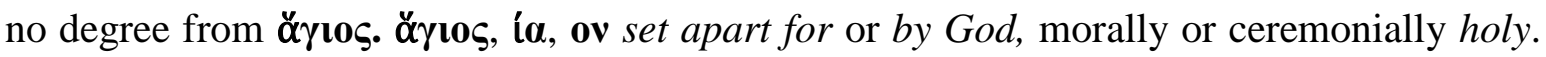
Suci di sini adalah tempat dimana Tuhan ada dari kata "ground" menunjukkan tempat dan holy" artinya suci. ${ }^{21}$ Jadi kudus atau kekudusan yang dimaksudkan di sini adalah kesucian seseorang melalui moralnya yang suci, suci dalam KBBI artinya "bersih, bebas dari dosa, bebas dari noda. Terbit dari hati yang suci. Jadi kesucian hati yang berhubungan dengan moral menjadi sesuatu yang penting dalam hal bersekutu dengan Tuhan sebab Tuhan itu suci di manapun kita berada ditempat itu suci sebab di situ, ada Tuhan yang kudus.

S.L. Jones mendefinisikan seksualitas sekurang-kurangnya dengan tiga macam pengertian (1) Seksualitas dalam penegrtian gender menunjuk pada cara, (2) Seksualitas dalam pengertian erotis menunjuk pada nafsu seksuil, keinginan untuk menyempurnakan hubungan dengan orang lain, mungkin tidak harus meihat emosi, intelek, rohani atau interaksi phisik dengan orang lain. (3) seksualitas dalam pengertian alat kelamin menunjuk pada alat vital, penis dan vagina. ${ }^{22}$

\section{Yosua 5:15}

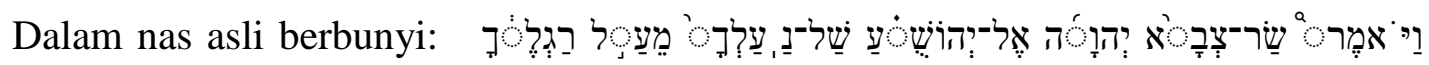
(Dan Panglima Balatentara TUHAN itu berkata kepada Yosua: "Tanggalkanlah kasutmu dari kakimu, sebab tempat engkau berdiri itu kudus.” Dan Yosua berbuat demikian).

Kata "kudus" di sini menggunakan bahasa Ibrani קָּ perbentuk noun common masculine singular absolute, kata benda dalam bentuk perintah kepada seorang laki-laki (bentuk tunggal) yaitu Yosua. Daalam KJV dari bahasa Ibrani ‘ שִ p qodesh \{ko'-desh artinya: 1) apartness, holiness,dalam kamus berarti dan NAS dari bahasa Ibrani

\footnotetext{
${ }^{19} \mathrm{KBBI}, 592$

${ }^{20}$ Kamus Bahasa Inggris-Indonesia, kata "Morally" artinya secara moral.

${ }^{21}$ Bible Work 8

${ }^{22}$ David G. Benner, Edit. Encyclopedia of Sychology (Grand Rapid, Machigan:Baker Books House,
} 1985). 
(qodesh) artinya: apartness, sacredness. Pada kedua kitab ini ditemukan masing-masing kata "apartness" pada bagian pertama tidak ditemukan artinya dalam kamus bahasa Inggris maka bagian kedua dari masing-masing terjemahan alkitab KJV yaitu holiness artinya "kesucian, kekudusan" sedangkan NAS yaitu sacredness dari kata dasarnya "sacred" keramat, suci, kudus artinya di sini menjelaskan "ground" artinya "tanah suci" Sedangkan kitab NIV/RSV tidak muncul dalam terjemaham bahasa Ibrani hanya memakai kata "holy" menurut kamus bahasa Inggris-Indonesia artinya "suci, kudus".

Alkitab BGT memakai kata “ŏ yı́ó adjective normal nominative masculine singular

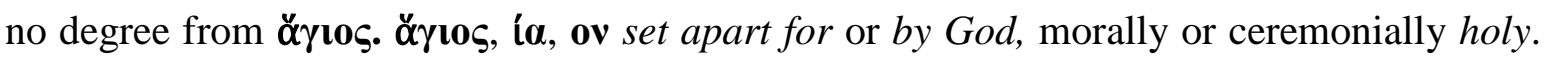
Suci di sini adalah tempat dimana Tuhan ada dari kata "ground" menunjukkan tempat dan holy" artinya suci. Jadi kudus atau kekudusan yang dimaksudkan di sini adalah kesucian seseorang melalui moralnya yang suci, suci dalam KBBI artinya "bersih, bebas dari dosa, bebas dari noda. Terbit dari hati yang suci. Jadi kesucian hati yang berhubungan dengan moral menjadi sesuatu yang penting dalam hal bersekutu dengan Tuhan sebab Tuhan itu suci di manapun kita berada ditempat itu suci sebab di situ, ada Tuhan yang kudus.

\section{Pentingnya Kekudusan di tengah Isu Pornografi}

Menurut Donald VanDe Veer, pornografi dapat menunjukkan pada lukisan dan tulisan yang bersifat seksuil mengenai laki-laki atau perempuan, pelacur maupun bukan pelacur, dan sekarang ada juga "pornografi anak-anak." 23 Terhadap marak dan berkembangnya pornografi dengan segala macam filosofi pendukungnya, John $\mathrm{H}$. Court mengkritik pornografi sebagai berikut: Pornografi itu menentang kehidupan, keluarga, wanita, anak-anak, seksualitas, menentang masyarakat, menentang lingkungan, melawan komunitas, budaya, suara hati manusia, dan melawan Allah. ${ }^{24}$

Secara iman Kristen pornografi adalah manipulasi dan eksploitasi dan perendahan gender, organ seks manusia dan nafsu seks manusia sebagai sarana liburan yang menyimpang dari tujuan Allah memberikan gender, organ seksual dan nafsu seks pada manusia. Orang Kristen yang mengerti dan mengenal Tuhan yang kita sembah adalah Kudus maka kekudusan hidup dihadapan Allah menjadi sesuatu yang sangat penting untuk melakukan persekutuan dengan Tuhan. Tuhan adalah Allah yang omni present yaitu Allah yang Maha kudus hadir di manapun berada, sebab Tuhan tidak bisa dibatasa oleh ruang dan waktu. Jadi, hidup kudus bukan waktu di gereja saja, melainkan di manapun kita berada sebab Tuhan mengetahui setiap perbuatan orang Kristen di tempat tersembunyi sekalipun.

\footnotetext{
${ }^{23}$ Lawrence C. Becker, “Pornography”, Encyclopedia of Ethics Vol.II (New York: Garland Publishing, 1992), 991

${ }^{24}$ Soekahar, H. Potret Pendeta di Tengah Masyarakat Plural Modern, (Malang: Gandum Mas, 2000), 133
} 
Apalagi di saat hamba Tuhan atau pelayanan Tuhan yang terlibat di dalam pelayanan di gereja harus menjaga hidup di dalam kekudusan, sebab Allah kita kudus. Yosua 5:15 Dan Panglima Balatentara TUHAN itu berkata kepada Yosua: “Tanggalkanlah kasutmu dari kakimu, sebab tempat engkau berdiri itu kudus." Dan Yosua berbuat demikian.

\section{Penyucian dari Kejahatan Moral}

Penyucaian dari kejahatan Moral sebenarnya merupakan bentuk lain dari hal dipisahkan untuk Allah. Pada imam zaman dahulu diminta untuk menyucikan diri mereka sebelum menhampiri kehadiran Allah (Kel. 19:22), dan orang percaya masa kini dihimbau agar memisahkan diri dari orang-orang fasik pada umumnya (II Kor.6:17,18), dari para guru palsu dan ajaran sesat (II Timotuis 2:21; II Yoh. 9,10), dan dari sifatnya sendiri yang jahat (Roma 6:11,12; Efesus 4:25-32; Kol. 3:5-9; I Tes.4:3-7). Paulus menulis bagi hambahamba Tuhan sebagai pemimpin yang melayani melalui pesan Firman Tuhan,'Saudarasaudaraku yang kekasih, karena kita sekarang memiliki janji itu, marilah kita menyucikan diri kita dari semua pencemaran jasmani dan rohani, dan dengan demikian menyempurnakan kita dalam takut akan Allah"(II Kor.7:1) ${ }^{25}$

Penyucian sebagai suatu tindakan dan dalam Firman Tuhan sebagai proses yang berkesinambungan; dalam beberapa ayat penyucian ini lebih bersifat jasmani, sedangkan dalam ayat-ayat lainnya pada dasarnya bersifat batiniah. Dalam semua ayat ini penyucian dipandang sebagai tindakan manusia dan bukan tindakan Allah. Allah telah memisahkan bagi diriNya sendiri setiap orang yang percaya kepada Kristus; kini orang percaya itu sendiri yang harus memisahkan dirinya bagi Allah agar Ia dipakai oleh Allah.

\section{Kekudusan di Dalam Bait Allah}

Bait yang kudus sama dengan bait Allah (1) Mazmur 5:8 atau (2) Habakuk 2:20. ${ }^{26}$ Mazmur 5:8 "Tetapi aku, berkat kasih setia-Mu yang besar, aku akan masuk ke dalam rumah-Mu, sujud menyembah 107atakan bait-Mu yang kudus dengan takut akan Engkau." Dan di dalam Habakuk 2:20 "Tetapi TUHAN ada di dalam bait-Nya yang kudus. Berdiam dirilah di hadapan-Nya, ya segenap bumi!" Jadi bait Allah itu kudus dan segala sesuatu khususnya manusia harus hidup kudus dihadapanNya. Dalam Roma 12:1-2 (ayat 1) "Karena itu, saudara-saudara, demi kemurahan Allah aku menasihatkan kamu, supaya kamu mempersembahkan tubuhmu sebagai persembahan yang hidup, yang kudus dan yang berkenan kepada Allah: itu adalah ibadahmu yang sejati.

\footnotetext{
${ }^{25}$ Henry C. Thiessen, Teologi Sistematika, 446

${ }^{26}$ W.N McElrath, Billy Mathias, Ensiklopedia Alkitab Praktis (Bandung: Lembaga Literatur Baptis,
} 2012), 20 
(ayat 2) "Janganlah kamu menjadi serupa dengan dunia ini, tetapi berubahlah oleh pembaharuan budimu, sehingga kamu dapat membedakan manakah kehendak Allah: apa yang baik, yang berkenan kepada Allah dan yang sempurna."

\section{Dipisahkan untuk Allah}

Dipisahkan untuk Allah mensyaratkan adanya pemisahan diri dari kecemaran. Hal ini berlaku untuk benda-benda yang mati. Demikian juga seperti perintah Tuhan kepada Yosua dan Raja Hizkia memerintahkan orang-orang Lewi untuk menyucikan rumah Yehova dengan mengeluarkan semua kotoran dari tempat kudus (II Tawarikh 29:5, 15-19). Pada umumnya dipisahkan untuk Allah mengandung gagasan positif dipersembahkan atau dikhususkan untuk Allah. Dengan pengertian semacam ini kemah sembayang (perbendaharaan) bait suci dikuduskan dengan semua perabotan yang di dalamnya seperti (kel. 40:10,11); Bil. 7:1). Seseorang dapat menyucikan rumahnya atau sebagian atau ladangnya (Imamat 27:14-16). Allah menguduskan semua anak sulung bangsa Israel untuk diriNya sendiri (Kel. 13:2; Bil. 3:13). Bapa menguduskan Anak (Yoh 10:36) dan anak menguduskan diriNya sendiri (Yoh.17:19). Orang Kristen dikuduskan ketika mereka bertobat (I Kor. 1:2; I Pet.1:2; Ibrani 10:14). Yeremia dikuduskan sebelum dia lahir (Yer. 1:5), dan Palulus berbicara soal dirinya yang sudah dipisahkan untuk Allah ketika masih dalam kadungan ibunya (Galatia 1:15). ${ }^{27}$

\section{Pengertian Kekudusan Bait Allah dalam Yosua 6:19}

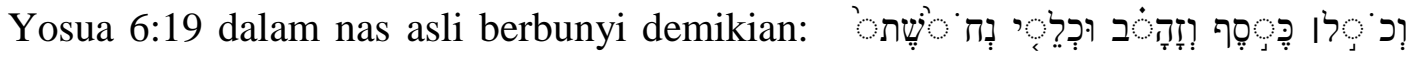

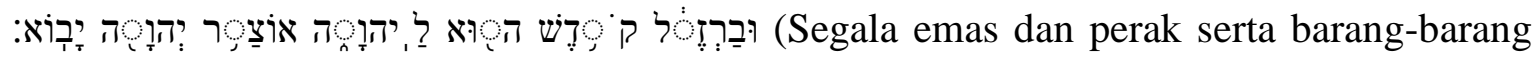
tembaga dan besi adalah kudus bagi TUHAN; semuanya itu akan dimasukkan ke dalam perbendaharaan TUHAN").

Kata "kekudusan" diterjemahkan oleh KJV "consecrated" tetapi oleh NAS diterjemahkan "holy" sedangkan RSVdan NIV menterjemahkan "sacred" (suci, kudus). Kata "consecrated" kata keterangan tempat mentahbiskan dan mengabdikan dri kata sifat suci. Dari perbedaan terjemahan penulis memakai kata"consecrated" dalam bahasa Ibrani

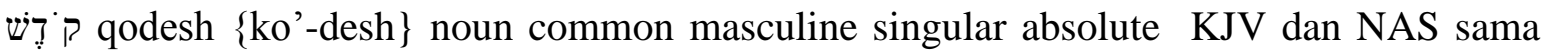
dalam terjemaham bahasa Ibrani dan sama juga dalam hal menerangkan sebagai kata kudus, saints adalah orang yang suci, nominative yaitu sebagai subjek dan kata benda keterangan tempat atau sesuatu yang harus ditahbiskan atau disucikan sedangkan yang melakukan perintah dari kata Ibrani קִּ̣ q qodesh \{ko'-desh $\}$ noun common masculine singular adalah kata benda maskulin tunggal artinya orang yang mengabdikan diri dengan memiliki dari kata sifat yaitu kudus "saints" seorang yang suci. Bentuk perintah kepada seorang laki-laki

\footnotetext{
${ }^{27}$ Henry C. Thiessen, Teologi Sistematika, (Malang: Gandum Mas, 1993),442
} 
yang mengabdikan diri harus memiliki kekudusan karena perintah yang mengandung hukuam (common) dan melakukan perintah yaitu masculine, perintah mentahbiskan. Jadi perintah mentahbiskan disini kepada seseorang laki-laki yang kudus. Jadi ayat ini menekankan kekudusan dalam melakukan pentahbisan oleh seorang laki-laki yang Kudus. Jadi Kekudusan seseorang dalam melakukan pentahbisan harus diwajibkan seorang yang kudus.

\section{Masalah Kerohanian Hamba Tuhan}

Pemahaman pengertian "rohani" atau "kerohanian" masih singpang siur di kalangan umat Kristiani. Sementara ada jemaat yang menganggap orang Kristen yang disiplin dalam mengatur saat teduhnya untuk membaca Alkitab dan berdoa, dialah manusia rohani. Yang lain lagi beranggapan, orang Kristen yang tidak merokok, tidak berdansa, tidak nonton film di gedung bioskop, dialah manusia rohani masih ada anggapan-anggapan yang lain. Hamba Tuhan sering dianggap sebagai pemimpin dan pembimbing dari umat kristiani, maka logisnya hamba Tuhan adalah manusia yang memiliki kerohanian atau memancarkan kehidupan rohani dalam pelayanannya.

Lawrence O. Richards dikutif oleh David Crawley mendefinisikan "kerohanian" kristiani adalah sebagai berikut: "Kerohanian kristiani yang benar adalah hidup dalam kehidupan manusia di dunia sekarang namun dalam kesatuan dengan Allah."28 Ciri spiritualitas kerohanian sebagai berikut: (1) spriualitas kekristenan di dasarkan atas wahyu Alkitab pada Allah yang berpribadi. (2) Spiritualitas Kristen membenarkan adanya nilai dunia ini dan kemanusiaan kami. (3) Spiritualitas Kristen mengakui realitas keberdosaan manusia dan perlunya lahir baru (4) Spiriulitas Kristen adalah perjalanan hidup yang panjang. (5) Spiritualitas Kristen adalah hidup yang berpusat pada Kristus (6) spiritualitas Kristen adalah suatu kehidupan yang dipimpin oleh Roh Allah. (7) Spiritualitas Kristen adalah hidup yang bersandar pada Allah Tritunggal. (8) Spiritualitas Kristen memiliki ekspresinya dalam persekutuan dengan tubuh Kristus.

Dalam pandangan Lee C. Wanak, ada beberapa patron spiritualitas (kerohanian) Kristen: (1) Pola Legalistik (legalistic Pattern). Pola ini berusaha mengahikimi kerohanian melalui prilaku yang kelihatan secara lahiria, pakaian, bahkan mode rambut. (2) Pola Libertin (Libertine Pattern). Pola ini mendasarkan dirinya pada kebebasan dalam Kristus menuju pada hal-hal yang ekstrem (Rm, 6:1) (3) Pola merasa diri hina (self-denigrating Pattern) (4) Pola merasa diri mantap (Self-affirming Pattern) Pola ini menekankan penebusan, tanpa mengenali dosa pribadi. (5) Pola Kemiskinan (Pattern of Privation). Pola ini mengindentikan kerohanian dengan kemiskinan, orang-orang miskin diindentikan

\footnotetext{
${ }^{28}$ David Crawley, “Spirituality and the Bible” Reaper (1992),3
} 
dengan umat Allah. (6) Pola kekayaan (Pattern of Wealth) Pola ini mengidetifikasikan kekayaan material dengan berkat Allah. ${ }^{29}$ Pola yang Alkitabiah adalah Pola spiritualitas yang dibangun berdasarkan wahyu Allah dan tetap menyesuai diri dengan Firman Tuhan. Pola kerohanian yang Tuhan kehendaki adalah hidup yang bersandar kepada Allah tritunggal dan memiliki ekspresi dalam persekutuan dengan tubuh Kristus.

Sesuai dengan kitab Yosua 6:9 kata perintah perintah dari kata Ibrani \{ko'-desh\} noun common masculine singular adalah kata benda maskulin tunggal artinya orang yang mengabdikan diri dengan memiliki dari kata sifat yaitu kudus "saints" seorang yang suci. Bentuk perintah kepada seorang laki-laki yang mengabdikan diri harus memiliki kekudusan karena perintah yang mengandung hukuam (common) dan שִ̣ podesh \{ko'desh berkaitan dengan seseorang yang melakukan perintah yaitu masculine, perintah mentahbiskan. ${ }^{30}$ Semankin jelas bagi kita betapa pentingnya kekudusan sebagai hambahamba Tuhan di tenga-tengah pelayanan yang Tuhan percayakan, sebab kekudusan merupakan keharusan sebagai seorang hamba Tuhan yang memimpin jemaat untuk mengerti rencana Tuhan membangun jemaat kudus di hadapanNya, oleh sebab itu hamba Tuhan harus menjadi teladan hidup kudus bagi mereka.

\section{Kekudusan Sebagai Perintah Tuhan}

Dalam kitab Yosua pasal 7: 13-26 menjelaskan bahwa orang yang bersalah ditemukan, dosanya diakui dan dihukum (ayat 16-18) dengan undian suci yang dilakukan secara hikmat, Akhan ditemukan sebagai orang yang telah melanggar hukum. Jadi perintah Tuhan "kuduskanlah" dalam Yosua 7:13 disebabkan karena Akhan telah melanggar perintah Tuhan, hal ini dijelaskan dalam ayat 24-26 bahwa Akhan telah menyentuh barangbarang yang dikhususkan itu telah tercemar. Karena itu dia sendiri menjadi "dikhususkan" karena dengan sengaja menyamakan dirinya dengan sesuatu yang berada di bawah kutuk

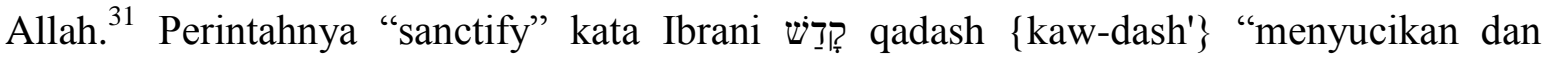
menguduskan" (bangsa Israe) dan dari kata קָָָ verb piel imperative masculine singular jadi kata kerja yang lebih dominan kepada laki-laki dalam bentuk tunggal. Jadi kata kuduskanlah adalah bentuk kata kerja yang dilakukan seseorang dengan dominannya kata masculin dan person singular dan kata ini ditemukan pada kata "Sanctify" sedangkan kata "consecrate" hanya menjelaskan bentuk keterangan dan kata kerja "berpisah, putus, terlepas atau mentahbiskan dan mengabdikan". 32

\footnotetext{
${ }^{29}$ H. Soekahar, Potret Pendeta, 37

${ }^{30}$ Bible Work 8 (Electronic).

${ }^{31}$ Tafsiran Masa Kini I Kejadian-Ester (Jakarta: Yayasan Bina Kasih, 1990),363

${ }^{32}$ Bible Work 8 (Electronic).
} 
Jika mereka tidak mentaati perintah ini, sama halnya dengan hilangnya kepercayaan (ayat 1) secara kusus adalah suatu ketidak setiaan dalam perjanjian. Demikianlah Israel harus menghimpun selaku umat perjanjian yang kudus atau disucikan bandingkan dengan Keluaran 19:10-11), takkala Tuhan datang di antara mereka selaku Hakim. Akhirnya Akhan dihukum dengan dilemparai dengan batu hingga mati dan segala yang telah dimilikinya dibakar dengan api. ${ }^{33}$

Satu tema yang menonjol dari kitab Yosua ini terdapat dalam "perntah-perintah" yang dikaitkan dengan bagaimana memperlakukan kota-kota di Pelestina yang telah dilakukan. Perundang-undangan mengenai larangan "haruslah kamu menumpas mereka sama sekali:... dan janganlah engkau mengasihiani mereka" ditemukan dalam U1.7:111;20:18 dan disahkan di dalam Yosua 6:17-19. Isilah "larangan". Kata kerja ini telah didefinisikan sebagai berikut"khususkan sesuatu atau seseorang sebagai persembahan yang tetap dan pasti untuk persembahan; dalam perang khususnya kota-kota dan penduduknya untuk dibinasakan; melaksanakan kehancuran ini; samasekali memusnakan penduduk dalam perang membunuh" "34 Inilah perintah Tuhan yang memiliki hubungan dengan kesucian seperti dijelaskan di atas dan akibatnya Akhan dihukum mati.

\section{Kata “Kuduskanlah" dalam Yosua 7:13}

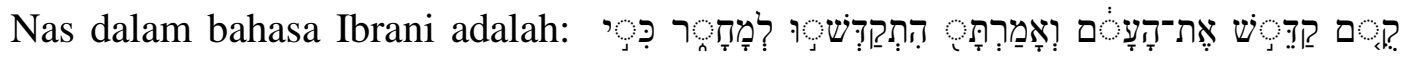

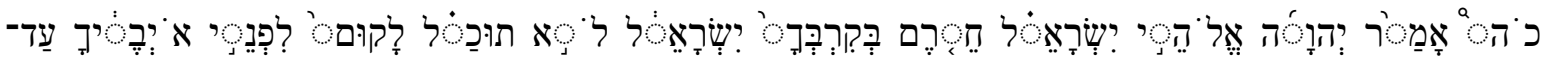
: הִסִירְֶֶ, Bangunlah, kuduskanlah bangsa itu dan katakan: Kuduskanlah dirimu untuk esok hari, sebab, demikianlah firman TUHAN, Allah Israel: Hai, orang Israel ada barang-barang yang dikhususkan di tengah-tengahmu; kamu tidak akan dapat bertahan menghadapi musuhmu, sebelum barang-barang yang dikhususkan itu kamu jauhkan dari tengah-tengah kamu).

Kata pertama dalam ayat ini "Kuduskanlah" diterjemakan oleh KJV/RSV "sanctify" sedangkan NAS/NIV menggunakan kata" consecrate" Kata "sanctify" dalam kata Ibrani קָּ qadash \{kaw-dash'\} "menyucikan dan menguduskan" sedangkan kata "consecrate" kata Ibrani קָָּ (qadash) meaning to be set apart or consecrated artinya"berpisah, putus, terlepas atau mentahbiskan dan mengabdikan." Kata "sanctify verb imperative aorist active 2nd person singular kata kerja bentuk lampau yang terjadi sekali waktu itu orang kedua tunggal artinya "engkau" (bentuk aktif orang kedua tunggal). Perintahnya "sanctify"

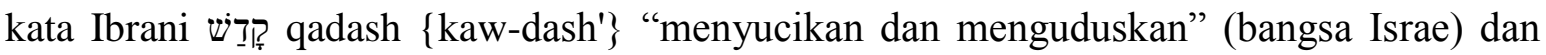
dari kata קָָּ verb piel imperative masculine singular jadi kata kerja yang lebih dominan kepada laki-laki dalam bentuk tunggal. Jadi kata kuduskanlah adalah bentuk kata kerja yang

\footnotetext{
${ }^{33}$ Tafsiran Masa ini I, 363.

${ }^{34}$ Survey Perjanjian lama, 233
} 
dilakukan seseorang dengan dominannya kata masculin dan person singular dan kata ini ditemukan pada kata "Sanctify" sedangkan kata "consecrate" hanya menjelaskan bentuk keterangan dan kata kerja "berpisah, putus, terlepas atau mentahbiskan dan mengabdikan". Jadi kata "kuduskanlah" di sini artinya bahwa tugas menguduskan dikerjakan dan dilakukan oleh seorang laki-laki kudus yang menerima mandat dari Tuhan.

Kata kedua "Kuduskanlah" oleh KJV/RSV sama dengan di atas yaitu "sanctify" kata Ibrani קָָָ q qadash \{kaw-dash'\} Meaning to consecrate, sanctify, prepare, dedicate, be hallowed, be holy, be sanctified, be separate ${ }^{35}$ "menjadi kudus". NAS dan NIV menggunakan kata"consecrate" terpisah, putus, terlepas atau mentahbiskan, mengabdikan"

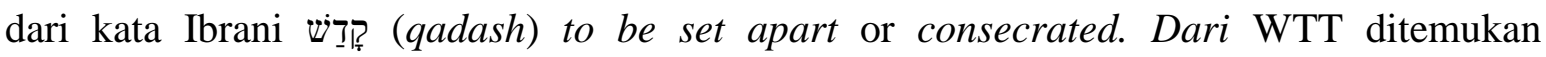
keterangan kata Ibrani קדש verb hithpael imperative masculine plural, menjelaskan kata kerja bentuk imperative yaitu bentuk perintah yang sifatnya sangat penting, tidak boleh tidak dan keterangan jamak maskulin. Dari kata"consecrate" oleh NAS/NIV ini ditemukan terjemahannya lebih lengkap dengan memberikan keterangan"verb hithpael masculine plural dari keterangan bentuk hithpael yaitu: "behave as (people who have been) consecrated, made holy, prove onesf. (to be) holy (subj). put onesf. (or each other) into the state of dedication or cultic purity, of a woman after menstruation". Kata "Kuduskanlah" artinya "berkelakuan seperti orang-orang yang telah ditahbiskan, membuat suci, menjadi suci, kemurnian seperti air, emas dan kesucian dari hati (purity) seperti wanita setelah dating bulan. Jadi kata "Kuduskanlah" menurut Alkitab adalah berkelakuan seperti orang yang sudah ditahbiskan menjadi suci, murni seperti air, emas maksudnya kesucian dari hati.

: kitab hukum Allah, lalu ia mengambil batu yang besar dan mendirikannya di sana, di bawah pohon besar, di tempat kudus TUHAN).

\section{Pengertian dari beberapa terjemahan "Kudus" Yosua 24:26}

Kata "kudus" dari terjemahan KJV/NAS/RSV memakai kata" sanctuary" Sedangkan terjemahan NIV kata"holy". Terjemahan KJV/NAS/RSV kata "sanctuary" artinya bagian dari gereja didekat altar atau tempat perlindungan, NIV kata "holy" artinya "suci, kudus" (tempat suci, kudus). Terjemahan KJV/NAS/RSV "sanctuary" dari kata

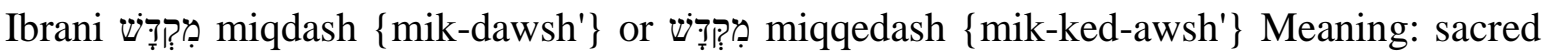
place, sanctuary, holy place, sanctuary, ( of the temple, of the tabernacl of Ezekiel's temple, of Jehovah ) "tempat suci", bagian dari gereja di dekat altar, disebut juga tempat

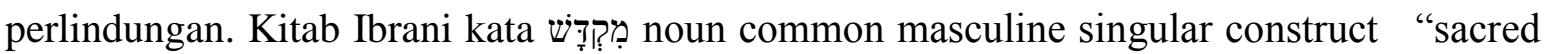
place atau sanctuary" Tempat suci, bagian dari gereja dekat altar atau disebut juga tempat

\footnotetext{
${ }^{35}$ Bible Work 8
} 
perlindungan itu adalah kata benda yang membangun, mendirikan bentuk tunggal maskulin sebagai tempat kudus Tuhan. Jadi kata kudus yang ditemukan lebih dominan dengan kata "sanctuary" dari terjemahan KJV/NAS/RSV dan setelah dihubungkan dari kata Ibrani

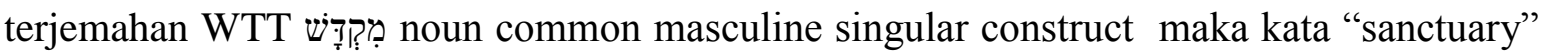
juga yang diterjemahkan dan ditemukan keterangan bahwa kata itu dijelaskan sebagai kata benda yaitu tempat kudus bagi Tuhan dari keterangan kata benda maskulin tunggal. Jadi kata kudus dalam ayat ini menerangkan tempat Kudus Tuhan adalah tempat suci, tempat kudus yang dibangun, didirikan sebagai tempat perlindungan, posisinya bagian dari gereja dekat altar.

\section{Kekudusan Sifat Allah bagi Hamba Tuhan Sebagai Pemimpin Tentang Allah Kudus}

Kata "kudus" berasal dari pokok kata Ibrani yang berarti: "memisahkan". Jika Tuhan Allah disebut kudus, hal itu berarti bahwa Allah dipisahkan dari segala dosa. Dalam 1 Samuel 2:2 disebutkan, tidak ada yang kudus seperti Tuhan, sebab tidak ada yang laian kecuali Tuhan." Dan dalam segala firman dan karyaNya di dalam sejarah itu tampak bahwa Tuhan Allah benar-benar tidak dapat bersekutu dengan dosa, bahwa Ia benar-benar kudus. ${ }^{36}$

Alkitab menjelaskan bahwa Allah itu kudus. Kata"kudus" ayat ini (Yosua 24:19) kata Ibrani קָדוֹ adjective masculine plural absolute (WTT) absolute adalah hal-hal mutlak (seperti kebenaran, keadilan dsb) kata sifat penuh, sepenuhnya, mutlak, nyata, pasti dengan

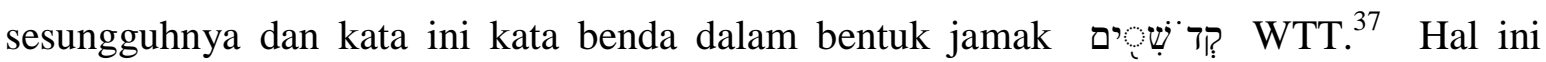
menjelaskan tentang kesempurnan Allah, tentang sifat-sifat Allah. Sifat adalah tabiat yang sudah menjadi pembawaan sesuatu subyek. ${ }^{38}$ Sifat-sifat itu memperkenalkan, membedakan, atau menganalisis subyek itu. Jadi sifat-sifat Allah adalah kesempurnaanNya. ${ }^{39}$ Alkitab yang mengatakan:'Hendaklah kamu menjadi kudus dalam seluruh hidupmu sama seperti Dia (Allah) yang kudus, yang telah memanggil kamu" (I Petrus 1:15). Sertiap kesempurnaan Allah menyatakan keseluruhan keberadaanNya. Kasih, bukan sebagian dari sifat Allah; tetapi Allah dalam keseluruhan keberadaanNya adalah kasih.Kasih ini relevan dengan pengajaran Firman bahwa tanpa kekudusan yang dimaksud dengan sifat Allah ini maka seseorang tidak kan melihat Allah, seperti dalam surat Ibrani menulis,"Berusahalah hidup damai dengan semua orang dan kejarlah kekudusan, sebab tanpa kekudusan tidak seorangpun akan melihat Tuhan" (Ibrani 12:14).

\footnotetext{
${ }^{36}$ Harun Hadiwijono, Iman Kristen, (Jakarta: BPK Gunung Mulia,1990),91

${ }^{37}$ Bible Work 8

${ }^{38}$ Charles C. Ryrie, Teologi Dasar I, 46

${ }^{39}$ Ibid
} 
Kesucaian adalah sifat yang Allah inginkan untuk diketahui secara khusus dalam zaman Perjanjian Lama (Yosua 24:19; Imamat 11:44; Yesaya 40:25; Hab.1:12). ${ }^{40}$ Penerapan, kesucian Allah yang mutlak dan harus itu berarti bahwa orang berdosa harus dipisahkan dari Dia kecuali ditemukan suatu jalan untuk menjadikan mereka suci ${ }^{41}$

\section{Kekudusan Allah dalam Yosua 24:19}

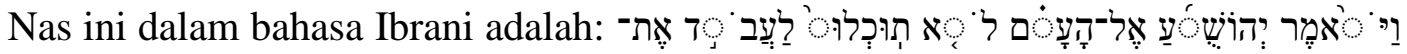
(Tetapi Yosua berkata kepada bangsa itu: "Tidaklah kamu sanggup beribadah kepada TUHAN, sebab Dialah Allah yang kudus, Dialah Allah yang cemburu. Ia tidak akan mengampuni kesalahan dan dosamu).

Kata"kudus" ayat ini kata Ibrani קָָזוֹ adjective masculine plural absolute (WTT) absolute adalah hal-hal mutlak (seperti kebenaran, keadilan dsb) kata sifat penuh, sepenuhnya, mutlak, nyata, pasti dengan sesungguhnya dan kata ini kata benda dalam

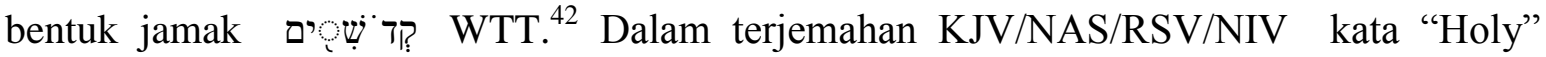
artinya "suci dan kudus" Kata "holy" terjemahan KJV dari kata Ibrani קָדוֹש \{kaw-doshe'\} Meaning: sacred, holy, Holy One, saint, set apart,terjemahan kamus "suci, kudus, dan ada kata Holy One, saint, set apart yang masing-masing artinya " Suci orangnya, orang yang suci perpisahan atau terlepas, sedangkan terjemahan NAS "holy" dari kata Ibrani קָזדוֹ (qadosh) Meaning: sacred, holy pribadi keramat, suci, kudus). Jadi kata "kudus, suci dalam KJV/NAS menterjemahkan Tuhan pribadi yang suci,kudus yaitu yang terlepas, terpisah dari dosa dan memutuskan hubungan dari dosa dan pendosa. Jadi kata kudus dalam ayat ini menjelaskan bahwa sifat kudus,suci Allah itu mutlak kebenaran, keadilan dengan sendirinya dosa dan orang berdosa akan terputus, terpisah dari Allah.

\section{Identitas Hamba Tuhan Sebagai Pemimpin}

Menurut Gary L. Harbaugh dalam bukunya Pastor as Person menggambarkan tentang identitas seorang hamba Tuhan. Orang Ibrani dan orang Kristen mula-mula, melihat manusia pribadi sebagai suatu kesatuan yang utuh, tidak dapat dipisah-pisahkan. Kata Ibrani untuk jiwa (nephesh) biasanya diterjemahkan dalam Perjanjian Baru dengan kata psyche, yang berarti diri, pikiran, kepribadian atau hidup. Setelah Allah membentuk manusia dari debuh tanah, kemudian menghebuskan nafas hidup ke dalam lubang hidungnya, lalu jadilah nephesh yang hidup (Kej.2:7). Di sini nephesh bukan suatu bagian dari manusia, tetapi seutuhnya manusia itu. ${ }^{43}$

\footnotetext{
${ }^{40}$ LAI

${ }^{41}$ Charles R. Ryrie, Teologi Dasar I, 51

${ }^{42}$ Bible Work 8.

${ }^{43}$ H. Soekahar, Potret Pendeta, 28.
} 
Dalam pertumbuhan dan perkembangannya hidupnya sebagai hamba Tuhan, tentu ada pengalaman yang melibatkan Allah dalam persoalan-persoalan jasmaninya, dalam persoalan-persoalannya sebagai manusia yang berpikir, memiliki perasaan dan berealisasi dengan sesamanya. Pilihan-pilihan sebagai manusia yang seutuhnya bersama-sama Allah yang menjadi pusat hidupnya aau sebaliknya, maka pada akhirnya akan membentuk kepribadian hamba Tuhan.

Pada awalnya pembentukan keperibadian manusia melalui penjelasan Alkitab tentang gambar Allah. Kejadian 1:26-27,"Berfirman Allah, baiklah kita menjadikan manusia menurut gambar dan rupa kita, suapaya mereka berkuasa atas ikan-ikan dan atas ternak atas segala binatang yang melata yang merayap di atas muka bumi." Dalam ayat 26 terdapat pernyataan tentang rencana Allah; termasuk dalam ayat ini terdapat pernyataan rencana Allah; terdapat dua istilah (Ibrani "tselem") dan (Ibrani “demuth") yang diterjemahkan sebagai "gambar" dan "rupa" Allah. ${ }^{44}$ Jadi gambar Allah ada dalam manusia yang menyatakan sifat-sifat Allah dalam hubungan kepada Allah dan sesama manusia. Semakin kita mengenal Allah, maka semakin kita mengetahui tentang diri kita. Karena kita diciptakan menurut gambar Allah, memiliki gagasan dalam pikiran bahwa sadar tentang Allah. $^{45}$

Pembentukan professional seorang hamba Tuhan sebagai pemimpin dalam pelayanan, setiap hamba Tuhan bergumul mengenai kewajibannya terhdap Allah, teman hidupnya dan anak-anaknya, orang lain dirumahnyaatau dalam komunitasnya, bagi Gereja dan bagi dirinya sendiri. Manafsirkan dilemma dunia; belas kasihan dan mau ikut terlibat dalam penderitaan dunia ini, murni hatinya menjadi agen penebusan Kristus bagi duniaini, berkorban untuk hal-hal yang menuntut pengorbanan. ${ }^{46}$

\section{Kekudusan Tuhan Hubungan dengan UmatNya}

Dia Allah yang Kudus (Yosua 24:19) dan beribadah kepada Tuhan ini justru di dalam hubungan dengan umatNya itulah Tuhan Allah tampak sebagai "Yang Kudus", yang tidak dapat bersekutu dengan dosa. Ia menghukum setiap orang yang menghinakan kekudusanNya (1 Sam.6:19) mati karena melihat ke Tabut Allah. ${ }^{47}$ Kekudusan Allah menuntut kekudusan umatNya: Umat Allah adalah sekutu Allah, juga harus hidup terpisah daripada segala yang dosa, dan mempersembahkan seluruh hidupnya bagi Tuhan Allahnya (Im. 19:2; 1 Pet.1:16). Tanpa hidup yang kudus, tidak mungkin ada persekutuan dengan Allah kudus. Di Yos 24:19 Yosua berkata, bahwa oleh karena Tuhan Allah adalah Allah

\footnotetext{
${ }^{44}$ Millard J. Erickson, Teologi Kristen, (Malang: Gandum Mas, 2003), 69

${ }^{45}$ Elmer L. Towns, Nama-nama Allah, (Yogyakarta: Yayasan ANDI, 1995), 22

${ }^{46}$ Rowland Croucher, Ministry bagian dua. A Christian Leadership Letter (summer 1992), 4

${ }^{47}$ Harun Hadiwijono, Iman Kristen, 90
} 
yang kudus, maka Ia tidak akan mengampuni kesalahan dan dosa Israel, apabilah Israel meninggalkan Tuhan dan beribadah kepada allah asing.

\section{Kepemimpinan sebagai Hamba Tuhan}

Hamba Tuhan sebagai pemimpin mempunyai pengaruh yang besar terhadap maju mundurnya sebuah gereja. Dalam hal ini seorang hamba Tuhan mengerti prinsip-prinsip kepemimpinan rohani di gereja. Menurut G.A. Cole, kepemimpinan adalah suatu proses dinamis di dalam kelompok, di mana seorang mempengaruhi orang lain untuk memberikan kontribusinya secara sukarela untuk mencapai tugas-tugas kelompok tersebut dalam suatu situasi yang diberikan. ${ }^{48}$

Kepemimpinan Kristen menurut James E. Means adalah pelayanan, bukan penguasaan menjadi kepala. Kepemimpinan Kristen adalah penaklukan diri berada di bawah kepemimpinan Kristus sebagai kepala, dengan maksud mengekspresikan tujuan gereja yang melayani, melengkapi orang-orang kudus dan memampukan pelayanan mereka kepada dunia ini. ${ }^{49}$ Para kepemimpin Kristiani adalah pemimpin yang berjiwa hamba, mengikuti prinsip-prinsip kepemimpinan Kristus dan pra rasulnya serta gerejamula-mula. Pengajaran ini direvansikan dengan kepemimpinan Yosua khususnya dalam Yosua 24:19 di mana Yosua sebagai pemimpin melakukan prinsip-prinsip kepemimpinan sebagai hamba dia telah memberikan contoh seperti kepemimpinan Kristus dalam hal memimpin orang orang Israel supaya beribadah kepada Tuhan, yaitu Allah yang kudus. Tentunya Yosua sebagai seorang pemimpin yang sanggup memberikan teladan kepada mereka terlebih dahulu dengan menunjukkan bagaimana sikap hormat kepada Tuhan sebagai Allah yang kudus dan dia juga tahu apa akibat dari orang yang yang tidak menghormati kekudusan Tuhan, akibatnya akan menghadapi penghukuman dari Tuhan. Itulah sebabnya dapat dikatakan kepemimpinan Yosua relevan dengan kepemimpinan Kristus dan para rasulnya (Markus 10:45; Matius 23:8-12; 20:25-28; Yoh. 13:12-27; I Petrus 5:2; Kis 20:28).

\section{KESIMPULAN}

Kekudusan Allah memberikan pemahaman yang benar bagi manusia untuk hidup melakukan yang berkenan dan sesuai dengan kehendak Allah. Sebab Allah Kudus maka kudus jugalah setiap orang yang hidup, menyembah dan melakukan perintah-perintahnya. Tanpa kekudusan mustahil manusia berkenan kepada Allah, sebab itu sudah selayaknya manusia harus menjaga hidup kudus dari dalam hatinya, sebab dari situlah akan terpancar kehidupan (Amsal 4:23). Sebagai pemimpin hamba yang melayani harus dapat mengajarkan kepada jemaat betapa pentingnya hidup kudus di hadapan Allah yang

\footnotetext{
${ }^{48}$ G.A Cole. Managemet: Theory and Practise (London: D.P Publication, 1993), 46.

${ }^{49}$ James E. Means, Leadership in Christian Ministry (Grand Rapids. Michigan: Baker Book House, 1989),46
} 
memiliki hubungan dengan segala aktivitas kehidupan dalam dunia ini. Khususnya dalam pelayanan di gereja harus benar-benar kudus dalam hal mempersembahkan hidup yang berkenan kepada Allah. Hal ini berkenaan dengan menghormati Tuhan dalam hadiratNya, tidak boleh hidup semberono, harus benar-benar menjaga kekudusan sebab di hadirat Allah itu, menunjukkan kehadiran Tuhan seperti yang diajarkan dalam kitab Yosua. Keberhasilan Yosua tidak dapat terlepas dari ketaatan dan kesetiaannya kepada perintah Tuhan yaitu supaya tetap menjaga kekudusan. Demikian juga hamba Tuhan sebagai pemimpin dalam gereja yang melayani harus diperhatikan hidupnya, supaya ibadah yang tidak kudus akan mendatangkan murka dari Tuhan. Kuduslah sebab Tuhan yang kita samba adalah kudus.

\section{REFERENSI}

Alkitab, LAI

Andrew E. Hill \& John H. Walton. Survei Perjanjian Lama,Gandum Mas, Malang, 2013.

Browning W.R.F. Kamus Alkitab, BPK Gunung Mulia, Jakarta, 2011.

Barth, C. Theologia Perjanjian Lama 2, BPK Gunung Mulia, Jakarta, 1981.

Baker D.L.. dkk. Pengantar Bahasa Ibrani, BPK Gunung Mulia, Jakarta, 2010.

Billy Mathias W.N McElrath, Ensiklopedia Alkitab Praktis. Yayasan Baptis Indonesia, Bandung, 2012.

Benner David G. Edit. Encyclopedia of Sychology Grand Rapid,:Baker Books House. Machigan, 1985.

Becker, Lawrence C. "Pornography”, Encyclopedia of Ethics Vol.II, New York: Garland Publishing, 1992

Bible Work 8 (Electronic).

David. "Crawley Spirituality and the Bible” Reaper, 1992.

Cole G.A. Managemet: Theory and Practise London: D.P Publication, 1993.

Cargas Harry James. Invisible Harmony Minneapolis, Fortress, 1997.

Erickson Millard J. Teologi Kristen, Gandum Mas, Malang, 2003.

Elmer L. Towns. Nama-nama Allah, Yayasan ANDI, Yogyakarta, 1995.

Green, Denis. Pengenalan Perjanjian Lama,: Gandum Mas, Malang, 1995.

H, Soekahar. Potret Pendeta di Tengah Masyarakat Plural Modern, Gandum Mas. Malang, 2000.

Hadiwijono Harun. Iman Kristen, BPK Gunung Mulia, Jakarta, 1990.

James E. Means. Leadership in Christian Ministry: Baker Book House, Grand Rapids. Michigan, 1989.

KBBI, "Kudus” Balai Pustaka.

Ryrie, Chales C. Teologi Dasar 1, Yogyakarta: Yayasan ANDI,Jakarta, 1992.

Stott John, Isu-Isu Global, Jakarta: Yayasan Bina Kasih, 1991.

Pasaribu, Marulak Pernikahan dan Keluarga Kristen, (Batu: Lit. YPPII, 2004),8

Ryrie, Chales R. Theologi Dasar I, Yogyakarta: Yayasan Andi, 1991.

Tafsiran Masa Kini I Kejadian-Ester, Jakarta: Yayasan Bina Kasih, 1990.

Rowland Croucher, Ministry bagian dua. A Christian Leadership Letter, summer 1992. 